ISSN: $2317-8957$

Volume 6, Number 1, Jun. 2018

\title{
PROTOCOLO PARA EXTRAÇÃO DE DNA PARA UTILIZAÇÃO EM AULAS PRÁTICAS NO ENSINO SUPERIOR
}

\author{
DNA EXTRACTION PROTOCOL FOR USE IN PRACTICAL LESSONS IN HIGHER \\ EDUCATION
}

\section{LIDIANE COELHO BERBERT ${ }^{1,2}$, JULIANA BARBOSA SUCCAR ${ }^{1,2}$, VINÍCIUS RIBEIRO FLORES ${ }^{1}$, IDA CAROLINA NEVES DIREITO ${ }^{1}$}

${ }^{1}$ Laboratório de Biotecnologia ambiental, Fundação Centro Universitário Estadual da Zona Oeste (UEZO), Rio de Janeiro, RJ, Brasil.

${ }^{2}$ Programa de Pós-Graduação em Ciência e Tecnologia Ambiental, Fundação Centro Universitário Estadual da Zona Oeste (UEZO), Rio de Janeiro, RJ, Brasil.

\section{RESUMO}

Cada vez mais a biotecnologia é importante no dia a dia, nas mais variadas áreas. A descoberta do DNA e sua manipulação trouxeram um mundo de possibilidades para a sociedade moderna, sendo a capacitação adequada dos profissionais dessa área um ponto crucial. A forma como são passadas as informações e a visualização do que está sendo aprendido através de aulas práticas são fatores determinantes no processo de ensinoaprendizagem. Tendo em vista, o peso das aulas práticas para a formação de profissionais mais capacitados e a limitação enfrentada por professores e instituições para oferecer tais práticas, foi realizado o desenvolvimento de um protocolo de extração de DNA para utilização em aulas práticas com base na experiência de nossa equipe. O protocolo de extração foi desenvolvido de modo a ser eficiente, mas com reagentes fáceis de serem adquiridos e manipulados, sendo inicialmente testado com leveduras presentes no fermento biológico. O protocolo se mostrou eficiente para a extração de DNA de leveduras e também foi testado para culturas puras bacterianas. O presente protocolo extraiu material genético em quantidade e em qualidade para amplificação, se mostrando um protocolo simples, relativamente barato e eficiente para utilização em aulas práticas.

Palavras chave: Aula prática, biotecnologia, extração de DNA

\begin{abstract}
Increasingly the biotechnology is important in everyday life, in the most varied areas. The discovery of DNA and its manipulation has brought a world of possibilities to modern society, and the proper training of professionals in this area is a crucial point. The way in which information is passed, the visualization of what is being learned, through practical classes, are determining factors in the teaching-learning process. Considering the weight of practical classes to train more qualified professionals and the limitation faced by professors and institutions to offer such practices, a DNA extraction protocol was developed to use in practical class with basis in team knowhow. The extraction protocol was developed to be more efficient, using regents easier to be acquired and manipulated, being initially tested with biological yeast. The protocol showed efficient to yeast DNA extraction and was also tested with pure bacterial culture. This protocol extracted genetic material with quantity and quality enough to amplification, it showed be a simple, cheaper and efficient protocol for practical class use.
\end{abstract}

Key words: DNA extraction, biotechnology, practical lessons

\section{INTRODUÇÃO}

Cada vez mais a biotecnologia é importante no dia a dia, seja para a produção de alimentos, na área da saúde ou da conservação e recuperação ambiental; no entanto, a descoberta e utilização destes potenciais biotec- nológicos na atualidade exigem muito mais que as observações fenotípicas realizadas historicamente para a seleção e o melhoramento genético animal e vegetal. As descobertas de Mendel, realizadas entre 1856 e 1863, foram e são muito úteis, mas a descoberta do DNA e a possibilidade de manipulação desta informação gené- 
tica abriram novos horizontes para a sociedade, a exemplo do tomate longa vida (VECCHIA \& $\mathrm{KOCH}, 2000$ ), produção da insulina (FERRO, 2010) e da clonagem animal (NEVES et al., 2010). Estas novas possibilidades exigem uma atualização do profissional que está no mercado de trabalho; mas, principalmente, a capacitação dos futuros profissionais de maneira adequada para o uso destas ferramentas.

Mas quais seriam os desafios para se capacitar estes futuros profissionais? Podemos destacar a necessidade de realização de aulas práticas, a dificuldade orçamentária para a manutenção, a dificuldade de infra-estrutura para realização, o suporte técnico para o preparo e, principalmente, a dificuldade para se atender às questões de biossegurança nestas aulas. Infelizmente, muitas das vezes a falta de um dos itens anteriores pode ser suficiente para desestimular o docente à realização da atividade prática. Mas, de fato, estas dificuldades existem?

Uma das práticas que sofre com as dificuldades acima citadas são as relacionadas com técnicas moleculares. $\mathrm{O}$ estudo do material genético necessita de reagentes com elevado grau de pureza que, consequentemente, são mais caros que os utilizados em atividades como microbiologia e bioquímica de rotina, isto porque o estudo das macromoléculas (DNA, RNA e proteínas) exige ausência de contaminantes de toda espécie, em especial de enzimas que possam degradar o material de interesse e de material genético que possa mascarar o alvo de estudo. Outra característica destes reagentes é que muitos são mutagênicos e carcinogênicos, principalmente os empregados na maioria dos protocolos de extração de DNA. É verdade que a utilização de kits comerciais para extração de DNA pode minimizar a problemática do uso de muitos destes reagentes, mas acabam por onerar ainda mais a realização da atividade prática, essencial para a capacitação profissional. Quanto a infra-estrutura e suporte técnico, os laboratórios destinados a aulas práticas são muitas vezes baseados em uma bancada e em uma pia, o que se apresenta em um fator limitante para a manipulação em segurança dos reagentes. $\mathrm{O}$ suporte técnico nico, quando disponível, é, muitas vezes, um profissional que tem de atender a uma grande diversidade de atividades experimentais. No que se refere à biossegurança, mesmo a literatura específica sobre protocolos de aulas práticas utilizam reagentes tóxicos (PETKOWICZ et al., 2007; MASTROENI \& GERN, 2008; CARVALHO et al., 2010; MARTINS et al., 2011), e o material a ser empregado para a extração de DNA pode ser fonte de contaminação, necessitando de maior atenção e uso dos devidos EPIs (Equipamentos de Proteção individual) e EPCs (Equipamentos de Proteção Coletiva) para realizar o correto manuseio e descarte do material.

Em um trabalho realizado por PETKOWICZ e colaboradores (2007) utilizam fígado de ratos, enquanto que outros recomendam um protocolo que faz uso de sangue (MARTINS et al., 2011; CARVALHO et al., 2010). Em um momento em que a bioética no uso de animais é tão discutida; bem como, ocorre a mobilização da sociedade para minimizar o uso de cobaias, o uso de fígados de animais em aulas práticas pode passar um descomprometimento com a formação ética e crítica do futuro profissional para o uso de animais. Embora o uso de sangue possa parecer mais simples, devemos realçar que, se empregando camundongos como fonte deste material, isto pode significar a morte de pelo menos dois animais para a realização da aula prática, ao contrário do uso de sangue de animais maiores em que pode ser considerado apenas uma doação. De qualquer maneira, deve-se ter a certeza de que os animais utilizados são sadios para que não exista risco de contaminação dos estudantes. Um protocolo que utilize sangue também abre a premissa de se poder usar sangue humano, mas mais uma vez a questão das condições sanitárias para coleta e manipulação devem ser adequadas, ou o que deveria ser um aprendizado pode se transformar em um grande problema para o docente e a instituição. A utilização da bactéria Escherichia coli (MASTROENI \& GERN, 2008) se apresenta uma alternativa mais adequada e segura, mas que em contraposição tem a exigência de cultivo prévio das células; logo, requisitando 
um suporte técnico para o preparo da aula prática.

Frente a estas dificuldades e à necessidade de realização da prática de extração de DNA para estudantes dos cursos de ensino superior em Ciências Biológicas e Tecnologia em Biotecnologia, realizamos o desenvolvimento de um protocolo para extração de DNA de fermento de pão seco para uso em aulas práticas no ensino superior.

\section{DESENHO METODOLÓGICO PÚBLICO-ALVO}

As disciplinas "Biologia Molecular" e "Técnicas Básicas em Biologia Molecular" estão inseridas, respectivamente, no terceiro e quarto período da matriz curricular dos cursos de graduação em Ciências Biológicas e em Tecnologia em Biotecnologia de uma universidade pública localizada na zona oeste do município do Rio de Janeiro/RJ. Os discentes dos cursos desta instituição apresentam um perfil diversificado, mas em sua maior parte são estudantes recém-saídos do ensino médio. Cada disciplina é oferecida pela formação de turmas compostas por no máximo 30 discentes. Os alunos são em sua maioria residentes na zona oeste do município do Rio de Janeiro, embora também sejam encontrados alunos oriundos de outros municípios, como Angra dos Reis, Barra do Piraí, Itaguaí, Maricá, São Gonçalo e Seropédica.

A disciplina de "Biologia Molecular" realiza a apresentação das macromoléculas DNA, RNA e Proteínas, bem como os mecanismos que asseguram a conservação da informação genética e os responsáveis pela expressão gênica; além de realizar a introdução às técnicas de estudo do DNA em seu módulo final. Geralmente a abordagem realizada é a introdução à extração de DNA empregando protocolos de extração de DNA de frutas e cebola amplamente divulgados na internet (CRUZ et al., 2012) e, em seguida, um protocolo de laboratório para a comparação entre estes métodos pelos alunos. $\mathrm{Na}$ disciplina "Técnicas Básicas em Biologia Molecular", que possui como pré-requisito a disciplina "Biolo- gia Molecular", é realizada a apresentação das principais técnicas para estudo da informação genética e da expressão gênica. Mais uma vez, é realizada a extração de DNA empregando um protocolo de laboratório para discussão da função dos reagentes empregados e obtenção de material genético para as técnicas a serem estudadas a seguir pelos discentes.

\section{DESCRIÇÃO DA ATIVIDADE}

a) Extração de DNA de fermento de pão:

A aula prática para extração de DNA nas disciplinas de Biologia Molecular e Técnicas de Biologia Molecular têm adotado o protocolo descrito a seguir. O mesmo faz uso do fermento biológico de pão seco, o qual apresenta em sua composição leveduras da espécie Saccharomyces cerevisiae.

Protocolo: Pesar 0,2g de fermento biológico seco em microtubo de $1,5 \mathrm{~mL}$ e adicionar $500 \mu \mathrm{L}$ de água ultrapura (ou água destilada e deionizada filtrada em filtro $0,22 \mu \mathrm{m}$ ) estéril. Homogeneizar. Adicionar $500 \mu \mathrm{L}$ de solução clorofórmio:álcool isoamílico $(24: 1)$ e $200 \mu \mathrm{L}$ de $\mathrm{NaCl} 5 \mathrm{M}$. Homogeneizar. Centrifugar a 10000 g por 10 minutos. Caso a instituição só disponha de centrífuga para tubo de ensaio, a centrifugação pode ser realizada fazendo uso de adaptadores e na maior velocidade atingida pelo equipamento. Após acentrifugação, o material no microtubo aparece em camadas (Figura 1). Coletar o sobrenadante, com cuidado para não pegar a fração logo abaixo, para um novo microtubo e reservar. Adicionar $500 \mu \mathrm{L}$ da solução clorofórmio: álcool isoamílico (24:1) e $200 \mu \mathrm{L}$ de $\mathrm{NaCl} 5 \mathrm{M}$ ao microtubo com o pellet (precipitado) e homogeneizar. Centrifugar a 10000 g por 10 minutos e coletar o sobrenadante, colocando-o no mesmo microtubo anteriormente reservado. Descartar o microtubo com o pellet. Adicionar $500 \mu \mathrm{L}$ de isopropanol gelado ao microtubo que recebeu o sobrenadante. Homogeneizar e incubar a $-20^{\circ} \mathrm{C}$ por no mínimo 1 hora. Se o período para realização da aula prática não permitir todo este tempo de incubação, deixar pelo menos 15 minutos. Passado o tempo de incubação, centrifugar o material a 10000 g por 
15 minutos. Descartar o sobrenadante, o que pode ser feito por inversão do microtubo, e adicionar $500 \mu \mathrm{L}$ de álcool etílico $70 \%(\mathrm{v} / \mathrm{v})$ gelado. Feito isso homogeneizar e centrifugar a 10000 g por 15 minutos. Após centrifugação, descartar novamente o sobrenadante e deixar os microtubos secando para a evaporação total do álcool. Finalmente, ressuspender o material em $50 \mu \mathrm{L}$ de água ultrapura e armazenar a $-20^{\circ} \mathrm{C}$ até o momento de utilização.

Vale ressaltar que o único componente considerado tóxico neste protocolo é o clorofórmio, o qual se utiliza menos de $0,5 \mathrm{ml}$ por amostra. Apesar do volume pequeno, se recomenda que a manipulação do frasco do reagente seja realizada em capela de exustão ou em ambiente bem arejado para o preparo do clorofórmio: álcool isoamílico (24:1). Este protocolo foi adaptado para realização de aulas práticas, tendo como amostras fermento biológico seco, mas em laboratório de pesquisa foram realizados testes com cultura bacteriana pura. Para emprego deste protocolo em cultura pura, fazer o crescimento bacteriano do meio de cultura recomendado para a estirpe em questão. Se a bactéria tiver sido cultivada em meio líquido: Realizar a concentração das células por centrifugação a $10000 \mathrm{~g}$ por 10 minutos. Descartar o sobrenadante e adicionar $500 \mu \mathrm{L}$ solução salina $0,85 \%(\mathrm{p} / \mathrm{v})$ estéril e homogeneizar. Centrifugar novamente a $10000 \mathrm{~g}$ por 10 minutos e descartar o sobrenadante. Adicionar $500 \mu \mathrm{L}$ de água ultrapura estéril. Homogeneizar. Seguir o protocolo descrito anteriormente a partir da adição de $500 \mu \mathrm{L}$ de solução clorofórmio: álcool isoamílico (24:1) e $200 \mu \mathrm{L}$ de $\mathrm{NaCl} 5 \mathrm{M}$. Se a bactéria tiver sido cultivada em meio sólido: Lavar a superfície da placa de petri com solução salina $0,85 \%(\mathrm{p} / \mathrm{v})$ estéril e coletar em um microtubo. Centrifugar a 10000 g por 10 minutos e descartar o sobrenadante. Adicionar $500 \mu \mathrm{L}$ de água ultrapura estéril. Homogeneizar. Seguir o protocolo descrito anteriormente a partir da adição de $500 \mu \mathrm{L}$ de solução clorofórmio: álcool isoamílico (24:1) e $200 \mu \mathrm{L}$ de $\mathrm{NaCl} 5 \mathrm{M}$. Ao final do processo, o produto da extração foi analisado em gel de agarose $0,8 \%$ em tampão TAE (Base
Tris $40 \mathrm{mM}$; Ácido Acético Glacial $20 \mathrm{mM}$ (NaOAc); EDTA 2,0 mM pH 8.3) $1 \mathrm{X}$ a $100 \mathrm{~V}$ por 40 minutos.

FIGURA 1. Fases em que se apresentam a amostra após a primeira etapa de centrifugação do protocolo de extração de DNA: Fração polar (onde está o DNA); resíduo celular (membranas, organelas, etc); Fração apolar (clorofórmio); e, precipitado ou pellet (resíduos celulares maiores).

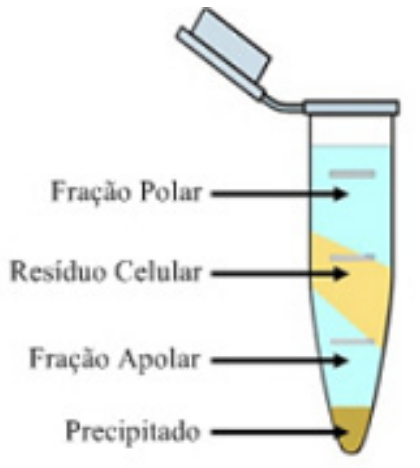

\section{RESULTADOS E DISCUSSÃO}

Como pode ser verificado na Figura 2, o protocolo desenvolvido permite a extração de DNA de leveduras (fermento biológico seco). O material extraído do fermento biológico seco mostrou bandas de DNA definidas, mas com pouco material (banda com intensidade fraca) e muito resíduo. A presença deste resíduo está relacionada, principalmente, à coleta de proteínas e resíduo celular juntamente com o sobrenadante, uma vez que o protocolo de extração de DNA foi utilizado durante a aula prática com alunos sem experiência prévia na técnica. A composição do fermento biológico seco também pode ter colaborado para a quantidade de resíduo observada, pois sua composição apresenta outros componentes que não só as células das leveduras. Este protocolo também foi testado em laboratório de pesquisa para bactérias, mostrando-se eficiente para este tipo de material (Figura 3). O material extraído de cultura pura de bactérias apresentou bastante material (banda com alta intensidade) e pouquíssimo re- 
síduo. Este resultado pode ter sido obtido tanto pela natureza do material, que possui somente células, como pela experiência dos que realizaram o protocolo de extração de DNA. O presente protocolo extraiu material genético em quantidade e em qualidade para amplificação (SUCCAR, 2017; BERBERT, 2017), se mostrando um protocolo simples, relativamente barato e eficiente para utilização em aulas práticas.

FIGURA 2. Eletroforese em gel de agarose $0,8 \%$ em TAE $1 \mathrm{x}$ com produto de extração de DNA de fermento biológico de pão seco (leveduras). MPM - Marcador de peso molecular; 1, 2, 3 e 4, DNA extraído das leveduras do fermento de pão.

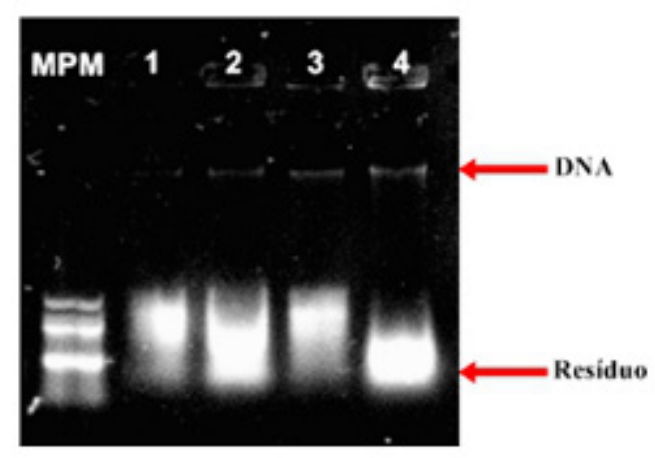

FIGURA 3. Eletroforese em gel de agarose $0,8 \%$ em TAE $1 \mathrm{x}$ com produto de extração de DNA de cultura pura de bactérias. MPM - Marcador de peso molecular; 1 e 2, DNA extraído de bactérias.

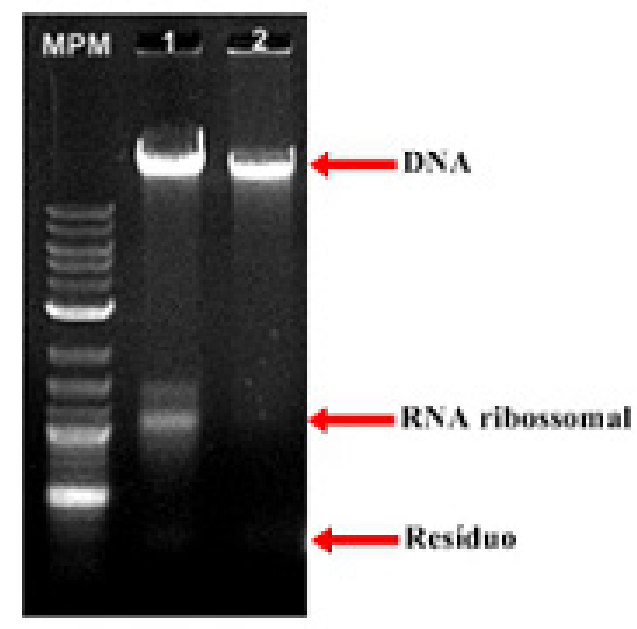

Segundo Ponte e colaboradores (2007), a forma como ocorre a comunicação dentro de sala de aula tem papel decisivo em todo o processo de ensino-aprendizagem. Já foi comprovada a importância e necessidade das aulas práticas em diversas disciplinas, em especial na área das Ciências da Natureza (ROSA, 2003). De acordo com Krasilchik (2005), a biologia é considerada uma das áreas de estudo mais relevantes e merecedoras da atenção dos alunos, assim como, ao mesmo tempo, pode se tornar a mais insignificante, dependendo da forma como o ensino é feito. Vale lembrar que, como citado por Borges e Lima (2007), o ensino da Biologia exige dos profissionais de ensino, reorganização do conteúdo e da metodologia adotada, além de novas estratégias para condução do ensino-aprendizagem, mais uma vez destacando a importância das aulas práticas, para demonstração e vivência do que está sendo ensinado.

\section{CONSIDERAÇÕES FINAIS}

O protocolo de extração de DNA desenvolvido para aulas práticas, se mostrou eficiente para extração de DNA de fermento de pão seco (leveduras) e cultura pura de bactérias. Suas etapas são simples e os reagentes fáceis de serem adquiridos e de baixa toxicidade quando comparados aos comumente utilizados em laboratórios. Apesar de simples, barato e eficiente, o presente protocolo permite ao discente a experiência com um protocolo que apresenta todas as etapas básicas presentes em muitos dos protocolos de extração de DNA utilizados amplamente pelos laboratórios de pesquisa.

\section{REFERÊNCIAS BIBLIOGRÁFICAS}

BERBERT LC. Diversidade de microrganismos cultiváveis a partir da bioprospecção em larvas de simulídeos (Diptera: Simuliidae) do Parque Nacional da Serra dos Órgãos. 2017. Dissertação (Mestrado em Ciência e Tecnologia Ambiental) - Centro Universitário da Zona Oeste, Rio de Janeiro. 
CARVALHO CV, RICCI G and AFFONSO R. 2010. Guia de Práticas em Biologia Molecular. Editora Yendis, São Caetano do Sul, São Paulo, 1-19.

CRUZ VLG, SOUSA PB, SOUSA L M, PASSOS AGF and LEAL RC. Extração do DNA da banana: aliando teoria e prática no ensino de ácidos nucleicos em Bioquímica. SIMPEQUI $10^{\circ}$ simpósio Brasileiro de Educação Química, Teresina/PI. Disponível em: <http://www.abq. org.br/simpequi/2012/trabalhos/219-13358. html>. Acesso em: 17.jul.2017.

FERRO ES. 2010. Biotecnologia translacional: hemopressina e outros peptídeos intracelulares. Estudos avançados, São Paulo, 24

(70):109-121.

KRASILCHIK M. 2005. Práticas de Ensino de Biologia. $4^{\mathrm{a}}$ ed. São Paulo: Editora da Universidade de São Paulo.

MARTINS T, NARCISO-SCHIAVON J L and SCHIAVON LL. 2011. Epidemiologia da infecção pelo vírus da hepatite C. Revista da Associação Medica Brasileira, São Paulo, 57(1):107-112.

MASTROENI MF and GERN RMM. 2008. Bioquímica: práticas adaptadas. São Paulo: Atheneu.

NEVES JP, MIRANDA KL and TORTORELLA RD. 2010. Progresso científico em reprodução na primeira década do século XXI. Revista Brasileira de Zootecnologia, Viçosa, 39:414-421.

PETKOWICZ, CLO, DORE AC, CARNEIRO CR, CUQUEL FL, ALMEIDA LB, CESAR MRA, DA SILVA MAN, DIAS NLC, PERNA PO, DALMOLIN Q, BERLEZA SLM, SATAUT JUNIOR SS. 2007. Bioquímica: aulas práticas. Departamento de Bioquímica. $7^{\mathrm{a}}$ edição, Curitiba:UFPR, 75-88.
PONTE JP, GUERREIRO A, CUNHA H, DUARTE J, MARTINHO H, MARTINS, $\mathrm{C}$, MENEZES L, MENINO $\mathrm{H}$, PINTO $\mathrm{H}$, SANTOS L, VARANDAS JM, VEIA L and VISEU F. 2007. A comunicação nas práticas de jovens professores de Matemática. Revista Portuguesa de Educação, Braga, 20(2):39-74.

ROSA CW. 2003. Concepções teoricometodológicas no laboratório didático de física na universidade de passo fundo. Revista Ensaio, Belo Horizonte, 5(2):94-108.

SUCCAR JL. Desenvolvimento de consórcio bacteriano com capacidade de fixação biológica de nitrogênio e biodegradação de pesticidas. 2017. Dissertação (Mestrado em Ciência e Tecnologia Ambiental) - Centro Universitário da Zona Oeste, Rio de Janeiro.

VECCHIA PTD and KOCH PS. 2000. Tomates longavida:Oquesão, comoforamdesenvolvidos? Horticultura Brasileira, Brasília, 18(1):03-04. 